A N N A L E S

UNIVERSITATIS M A R A E C URIE-SKŁODOWSKA

LUBLIN - POLONIA

VOL. XXXI, 2

SECTIO J

2018

Uniwersytet Marii Curie-Skłodowskiej w Lublinie. Wydział Pedagogiki i Psychologii

\title{
AGNIESZKA BUCZAK
}

ORCID: 0000-0002-7029-1259

agnieszka-buczak@wp.pl

\section{Postawy żywieniowe a radzenie sobie ze stresem studentów kierunków nauczycielskich}

Dietary Attitudes and Coping with the Stress of Students of Teaching Faculties

\section{STRESZCZENIE}

Postawy żywieniowe - rozumiane jako stosunek do własnego sposobu odżywiania się, obejmujący komponent poznawczy, emocjonalny i behawioralny - mają źródło w światopoglądzie jednostki. W toku prac nad autorską Skalą Postaw Żywieniowych wyodrębniono pięć typów postaw wobec odżywiania. Chociaż nie są one oceniane w kategoriach prozdrowotne - antyzdrowotne, wysokie nasilenie każdej z nich może mieć negatywne konsekwencje dla zdrowia. Jednym z korelatów postaw żywieniowych mogą być strategie radzenia sobie, a sposób odżywiania (np. odchudzanie się, eksperymentowanie $z$ dietami, religijny post, nadmierne jedzenie) może być postrzegany w kategoriach radzenia sobie z problemami życia codziennego.

Grupę badanych stanowiło 387 studentów kierunków nauczycielskich - młodych dorosłych, którzy podjęli pierwsze świadome decyzje żywieniowe. Prawdopodobnie część z nich będzie w przyszłości pracować z dziećmi i młodzieżą oraz oddziaływać na sposób odżywiania się uczniów. W badaniach własnych, oprócz autorskiego narzędzia do badania postaw żywieniowych, wykorzystano skalę Mini-COPE do analizy strategii radzenia sobie. Analiza wyników badań wykazała, że zależności między postawami żywieniowymi a radzeniem sobie częściej są obserwowane u kobiet. Zarówno nadmierne jedzenie, jak i odchudzanie się są traktowane przez badane studentki w kategoriach unikania stresu.

Słowa kluczowe: postawy żywieniowe; radzenie sobie; zdrowie; studenci 


\section{WPROWADZENIE}

Postawy żywieniowe, jako ważny element stylu życia, stanowią istotny czynnik warunkujący zdrowie jednostki. Koncentracja na sposobie odżywiania w trosce o zdrowie jest związana $\mathrm{z}$ tradycyjnym podejściem prosomatycznym $\mathrm{w}$ edukacji zdrowotnej (Woynarowska 2017a, s. 100) oraz z ideologią healthizmu (Borowiec, Lignowska 2012, s. 96), która w skrajnej postaci może przyjąć postać „obsesji zdrowia" (Woynarowska 2017b, s. 90). Nadmierna koncentracja na zdrowym odżywianiu może prowadzić do zagrażającej zdrowiu, a nawet życiu, ortoreksji (Kędra 2011, s. 169-170). Jednym z kluczowych modeli współczesnej edukacji zdrowotnej jest koncepcja ukierunkowana na rozwijanie umiejętności życiowych, w tym umiejętności radzenia sobie ze stresem (Woynarowska 2017a, s. 100).

Przyjęta w niniejszej pracy koncepcja postaw żywieniowych nawiązuje do psychologicznego rozumienia postawy jako względnie trwałej tendencji do pozytywnego lub negatywnego wartościowania określonego obiektu. Wartościowanie to może mieć charakter zarówno wzbudzanej przez ten obiekt emocji, bardziej chłodnej oceny, jak i bezwiednej automatycznej reakcji (Wojciszke 2013, s. 200). Postawy żywieniowe można określić jako „ustosunkowanie się do wielu różnych problemów, składających się na całość żywienia jednostki lub rodziny" (Narojek 1993, s. 50). Struktura postaw żywieniowych obejmuje trzy komponenty: poznawczy (wiedzę i przekonania związane z odżywianiem), emocjonalny (np. radość, przyjemność, wstręt, satysfakcja z diety, jedzenia czy sposobu odżywiania), behawioralny (praktyki żywieniowe). Obiektem postaw żywieniowych uczyniono własny sposób odżywiania.

Na możliwość powiązania postaw żywieniowych ze strategiami radzenia sobie wskazuje Zintegrowany Model Odżywiania J. Ogden, uwzględniający podmiotowe czynniki sposobu odżywiania (Ogden 2011, s. 291), a także analiza psychologicznych funkcji jedzenia, do których zalicza się m.in. redukcję napięcia i wyrażania emocji (Niewiadomska, Kulik, Hajduk 2005, s. 21-22).

\section{MATERIAŁ I METODA}

Dla potrzeb niniejszego opracowania wykorzystano materiał badawczy uzyskany w ramach realizacji szerszego projektu badawczego pt. „Wybrane korelaty typów postaw żywieniowych przyszłych nauczycieli”. Na podstawie analizy czynnikowej w badaniach pilotażowych wyodrębniono pięć typów postaw żywieniowych wobec własnego sposobu odżywiania. W procesie konstrukcji narzędzia badawczego przyjęto założenie, że źródłem postaw jest światopogląd jednostki, rozumiany jako zbiór doświadczeń intelektualnych i emocjonalnych określających relację osoby do rzeczywistości (Kowalewska, Graeber 2003). Konsekwencją przyjęcia światopoglądu jest praktykowanie związanej z nim ideologii, która staje się nie tylko zbiorem wartości i sposobów oglądania świata, ale też praktyką 
społeczną, konkretnym działaniem (Abucewicz 2008; Fiske 1999). Postawy nie są oceniane w kategoriach prozdrowotne - antyzdrowotne, chociaż wysokie nasilenie każdej z postaw może być czynnikiem zagrażającym zdrowiu.

Wyodrębniono następujące postawy wobec odżywiania:

1. Postawa anorektyczny dietetyzm - związana z obecnym w naszej kulturze kultem ciała, a w szczególności szczupłej sylwetki. Wyraża się w ograniczeniu ilości spożywanych potraw (Sołtysiak 2013; Józefik 2010; Głębocka 2010; Ziółkowska 2001).

2. Postawa religijna - opiera się na praktykowaniu religijności, a zasady religijne (etyka umiaru, okresowy post, w niektórych religiach zakaz spożywania pewnych potraw, przypisywanie sakralnego znaczenia niektórym produktom żywnościowym) są zasadniczym regulatorem relacji do jedzenia (Mariański 2004; Zwoliński 2006, 2008; Woźniak 2013; Leszczyński 2014; Buczak 2017).

3. Postawa wegetariańska - wynika z szacunku człowieka do zwierząt, jest traktowana jako rodzaj „świeckiej religii”, często występuje w szerszym kontekście ekologicznym (Ziemlański, Budzyńska-Topolowska 1997; Dyczewska 2006; Singer, Mason 2012; Kwasek, Obiedzińska 2014).

4. Postawa hedonistyczna - związana ze światopoglądem konsumpcyjnym, gdzie jedzenie jest źródłem przyjemności i sposobem na zaspokojenie wielu potrzeb. W efekcie często prowadzi do niekontrolowanego objadania się (Ogińska-Bulik 2004, 2016; Ogden 2011; Makara-Studzińska, Buczyjan, Morylowska 2007).

5. Postawa ortorektyczno-eksperymentalna - jest konsekwencją ideologii helthizmu, czyli zapoczątkowanej na przełomie XX i XXI w. mody na zdrowy styl życia. Polega na dążeniu do spożywania wyłącznie zdrowych produktów żywnościowych (Borowiec, Lignowska 2012; Kędra 2011; Babicz-Zielińska, Zabrocki 2007).

Badania korelacyjne - z wykorzystaniem autorskiej Skali Postaw Żywieniowych oraz narzędzia Mini-COPE w opracowaniu N. Ogińskiej-Bulik i Z. Juczyńskiego do badania strategii radzenia sobie - przeprowadzono na grupie 387 studentów kierunków nauczycielskich z trzech uczelni wyższych Polski południowo-wschodniej i wschodniej: Akademii Wychowania Fizycznego w Białej Podlaskiej, UMCS w Lublinie oraz Uniwersytetu Rzeszowskiego. W grupie badanych $70 \%$ to kobiety, co jest związane z przewagą studentek na kierunkach przygotowujących do zawodu nauczyciela.

\section{WYNIKI}

Zebrany materiał pozwolił na przeprowadzenie analizy struktury postaw żywieniowych badanych studentów oraz ich korelację ze strategiami radzenia sobie. Szczegółowe statystyki dotyczące nasilenia postaw żywieniowych osób badanych przedstawia tab. 1. 
Tab. 1. Postawy żywieniowe studentów kierunków nauczycielskich - statystyki opisowe

\begin{tabular}{|c|c|c|c|c|c|c|}
\hline \multicolumn{7}{|c|}{ Typy postaw żywieniowych (średnie ważone) } \\
\hline \multicolumn{2}{|c|}{$\begin{array}{l}\text { Statystyki } \\
\text { opisowe }\end{array}$} & $\begin{array}{c}\text { Anorektyczny } \\
\text { dietetyzm }\end{array}$ & Religijny & Wegetariański & Hedonistyczny & $\begin{array}{l}\text { Ortorektyczno- } \\
\text {-eksperymentalny }\end{array}$ \\
\hline \multicolumn{2}{|l|}{$\mathrm{N}$} & 387 & 387 & 387 & 387 & 387 \\
\hline \multicolumn{2}{|c|}{ Średnia } & 2,57 & 2,63 & 1,66 & 2,96 & 3,56 \\
\hline \multicolumn{2}{|c|}{ Mediana } & 2,56 & 2,64 & 1,56 & 2,90 & 3,67 \\
\hline \multicolumn{2}{|c|}{$\begin{array}{c}\text { Odchylenie } \\
\text { standardowe }\end{array}$} & 0,87 & 1,07 & 0,57 & 0,66 & 0,69 \\
\hline \multicolumn{2}{|c|}{ Minimum } & 1,00 & 1,00 & 1,00 & 1,55 & 1,33 \\
\hline \multicolumn{2}{|c|}{ Maksimum } & 4,88 & 4,82 & 4,67 & 4,91 & 5,00 \\
\hline \multirow{3}{*}{ Percentyle } & 25 & 1,87 & 1,73 & 1,22 & 2,54 & 3,11 \\
\hline & 50 & 2,56 & 2,63 & 1,55 & 2,91 & 3,67 \\
\hline & 75 & 3,25 & 3,45 & 1,89 & 3,36 & 4,00 \\
\hline
\end{tabular}

Źródło: badanie własne.

Analiza średnich i median typów postaw wobec własnego sposobu odżywiania badanych studentów pozwala zauważyć najwyższe nasilenie postawy ortorektyczno-eksperymentalnej. Oznacza to, że respondenci przywiązują dużą wagę do zdrowego odżywiania, podejmując eksperymenty dietetyczne. Jednocześnie najniższe wartości tendencji centralnych odnotowano w zakresie postawy wegetariańskiej, co świadczy o stosunkowo niewielkim zainteresowaniu tego typu dietami (tab. 1).

W tab. 2 przedstawiono strategie radzenia sobie obliczone jako wartości średnie w strukturze czynnikowej Mini-COPE. Ponadto porównano wyniki uzyskane w każdej z siedmiu podskal w grupach badanych studentów wyodrębnionych ze względu na płeć.

Tab. 2. Strategie radzenia sobie ze stresem studentów kierunków nauczycielskich - różnice średnich w grupach badanych kobiet i mężczyzn

\begin{tabular}{|c|c|c|c|c|c|}
\hline $\begin{array}{c}\text { Strategie radzenia sobie - } \\
\text { struktura czynnikowa }\end{array}$ & $\begin{array}{c}\text { Ogółem } \\
\mathrm{N}=387 \\
\mathrm{M}(\mathrm{SD})\end{array}$ & $\begin{array}{c}\text { Kobiety } \\
\mathrm{N}=271 \\
\mathrm{M}(\mathrm{SD})\end{array}$ & $\begin{array}{c}\text { Mężczyźni } \\
\mathrm{N}=117 \\
\mathrm{M}(\mathrm{SD})\end{array}$ & Istotność & MWU \\
\hline Aktywne Radzenie Sobie & $4,12(1,04)$ & $4,17(1,04)$ & $4,00(1,03)$ & 0,172 & 1,360 \\
\hline Bezradność & $1,90(1,10)$ & $1,88(1,09)$ & $1,95(1,12)$ & 0,537 & $-0,615$ \\
\hline Poszukiwanie Wsparcia & $4,21(1,38)$ & $4,50(1,28)$ & $3,53(1,36)$ & $0,001 * * *$ & 6,356 \\
\hline Zachowania Unikowe & $2,96(1,08)$ & $3,04(1,05)$ & $2,78(1,13)$ & $0,022^{*}$ & 2,275 \\
\hline Zwrot ku Religii & $2,39(1,94)$ & $2,47(1,94)$ & $2,18(1,95)$ & 0,166 & 1,364 \\
\hline Akceptacja & $3,80(1,28)$ & $3,84(1,27)$ & $3,70(1,29)$ & 0,616 & 0,486 \\
\hline Poczucie Humoru & $2,19(1,39)$ & $1,97(1,29)$ & $2,69(1,50)$ & $0,001 * * *$ & $-4,201$ \\
\hline
\end{tabular}

$* \mathrm{p}<0,05 ; * * \mathrm{p}<0,01 ; * * * \mathrm{p}<0,01$

Źródło: badanie własne. 
Analiza danych zawartych w tab. 2 wykazała, że badane kobiety statystycznie częściej niż mężczyźni stosują strategie radzenia sobie związane z poszukiwaniem wsparcia emocjonalnego i instrumentalnego, a także z zachowaniami unikowymi. Tymczasem studenci mężczyźni częściej próbują wykorzystywać poczucie humoru w radzeniu sobie ze stresem i problemami życia codziennego. W zakresie pozostałych czterech czynników związanych ze strategiami radzenia sobie nie odnotowano istotnych różnic między grupami wyodrębnionymi ze względu na płeć.

Tab. 3 przedstawia wyniki analizy zależności między strategiami radzenia sobie a postawami wobec odżywiania.

Tab. 3. Postawy żywieniowe studentów kierunków nauczycielskich a radzenie sobie ze stresem analiza korelacyjna Tau-b Kendalla

\begin{tabular}{|c|c|c|c|c|c|c|c|c|c|c|}
\hline \multirow[t]{2}{*}{ Czynnik } & \multicolumn{2}{|c|}{$\begin{array}{c}\text { Anorektyczny } \\
\text { dietetyzm }\end{array}$} & \multicolumn{2}{|c|}{ Religijny } & \multicolumn{2}{|c|}{ Wegetariański } & \multicolumn{2}{|c|}{ Hedonistyczny } & \multicolumn{2}{|c|}{$\begin{array}{c}\text { Ortorektyczno- } \\
\text {-eksperymentalny }\end{array}$} \\
\hline & K & M & $\mathrm{K}$ & M & $\mathrm{K}$ & M & $\mathrm{K}$ & $\mathrm{M}$ & K & M \\
\hline \multirow{2}{*}{$\begin{array}{c}\text { Aktywne } \\
\text { Radzenie } \\
\text { Sobie }\end{array}$} & \multicolumn{2}{|c|}{0,02} & \multicolumn{2}{|c|}{$-0,03$} & \multicolumn{2}{|c|}{$-0,05$} & \multicolumn{2}{|c|}{$-0,01$} & \multicolumn{2}{|c|}{$0,25 * * *$} \\
\hline & $-0,03$ & 0,12 & $-0,06$ & 0,03 & $-0,09 *$ & 0,00 & $-0,01$ & $-0,03$ & $0,25 * * *$ & $0,23^{* * *}$ \\
\hline \multirow{2}{*}{ Bezradność } & \multicolumn{2}{|c|}{$0,17 * * *$} & \multicolumn{2}{|c|}{0,00} & \multicolumn{2}{|c|}{0,06} & \multicolumn{2}{|c|}{$0,22 * * *$} & \multicolumn{2}{|c|}{$-0,05$} \\
\hline & $0,21 * * *$ & 0,11 & 0,00 & 0,05 & $0,13 * *$ & $-0,08$ & $0,22 * * *$ & $0,22 * * *$ & $-0,08$ & 0,04 \\
\hline \multirow{2}{*}{$\begin{array}{c}\text { Poszukiwanie } \\
\text { Wsparcia }\end{array}$} & \multicolumn{2}{|c|}{0,04} & \multicolumn{2}{|c|}{$0,08^{*}$} & \multicolumn{2}{|c|}{0,04} & \multicolumn{2}{|c|}{0,02} & \multicolumn{2}{|c|}{$0,17 * * *$} \\
\hline & 0,00 & 0,01 & 0,07 & 0,06 & $-0,04$ & $-0,02$ & $-0,02$ & 0,05 & $0,14 * *$ & $0,22 * *$ \\
\hline \multirow{2}{*}{$\begin{array}{c}\text { Zachowania } \\
\text { Unikowe }\end{array}$} & \multicolumn{2}{|c|}{$0,12 * *$} & \multicolumn{2}{|c|}{$0,08 *$} & \multicolumn{2}{|c|}{0,04} & \multicolumn{2}{|c|}{$0,19 * * *$} & \multicolumn{2}{|c|}{0,10 ** } \\
\hline & $0,09^{*}$ & $0,15^{*}$ & 0,03 & $0,21 * *$ & 0,05 & $-0,08$ & $0,22 * * *$ & 0,12 & 0,06 & $0,20 * *$ \\
\hline \multirow{2}{*}{$\begin{array}{l}\text { Zwrot ku } \\
\text { Religii }\end{array}$} & \multicolumn{2}{|c|}{0,01} & \multicolumn{2}{|c|}{$0,48 * * *$} & \multicolumn{2}{|c|}{$0,08^{*}$} & \multicolumn{2}{|c|}{0,04} & \multicolumn{2}{|c|}{0,03} \\
\hline & 0,00 & 0,02 & $0,47 * * *$ & $0,49 * * *$ & 0,04 & $0,16^{*}$ & 0,08 & $-0,08$ & 0,04 & 0,01 \\
\hline & 0,0 & & & & -0 , & & 0,14 & $* * *$ & 0,13 & *** \\
\hline $\mathrm{A}$ & 0,03 & 0,08 & $-0,01$ & $-0,04$ & $-0,02$ & $-0,08$ & $0,10^{*}$ & $0,24 * * *$ & $0,13 * *$ & 0,13 \\
\hline Poczucie & 0,0 & & & & -0 , & & 0,0 & & 0,1 & $0 * *$ \\
\hline Humoru & $-0,01$ & 0,13 & $-0,03$ & $-0,04$ & 0,03 & 0,05 & 0,09 & 0,09 & 0,06 & $0,24 * * *$ \\
\hline
\end{tabular}

$* \mathrm{p}<0,05 ; * * \mathrm{p}<0,01 ; * * * \mathrm{p}<0,01$

Źródło: badanie własne.

$\mathrm{Z}$ analizy danych zawartych w tab. 3 wynika, że istnieje istotna statystycznie dodatnia zależność między aktywnym radzeniem sobie (obejmującym również planowanie i pozytywne przewartościowanie) a nasileniem postawy ortorektyczno-eksperymentalnej wobec własnego sposobu odżywiania. Oznacza to, że zainteresowanie zdrową żywnością, eksperymentowanie ze zdrowymi dietami oraz gotowość do zmiany sposobu odżywiania na bardziej prozdrowotny można wyjaśnić w kategoriach zadaniowego podejścia w radzeniu sobie ze stresem i problemami. 
Bezradność jako czynnik radzenia sobie przejawiający się strategiami Zażywania Substancji Psychoaktywnych, Zaprzestania Działań i Obwiniania Siebie w sposób istotny statystycznie koreluje dodatnio z gotowością do podejmowania diet odchudzających (typ postawy - anorektyczny dietetyzm) oraz z nadmiernym jedzeniem (typ postawy - hedonistyczny). W sytuacji stresu wyrazem bezradności wobec pojawiających się problemów może być zarówno unikanie jedzenia, jak i jedzenie dla przyjemności. Warto dodać, że postawa hedonistyczna w sposób istotny statystycznie koreluje dodatnio z Akceptacją jako strategią radzenia sobie opartą na bierności.

Poszukiwanie Wsparcia, jako trzeci czynnik Mini-COPE, obejmuje Poszukiwanie Wsparcia Emocjonalnego, zaliczane do strategii ukierunkowanych na emocje, oraz Poszukiwanie Wsparcia Instrumentalnego jako strategię skoncentrowaną na problemie (Juczyński, Ogińska-Bulik 2012, s. 55). Poszukiwanie Wsparcia zarówno w wymiarze emocjonalnym, jak i instrumentalnym w sposób istotny statystycznie koreluje dodatnio z ortorektyczno-eksperymentalnym typem postawy żywieniowej. Poszukiwanie Wsparcia, podobnie jak Aktywne Radzenie Sobie, jest wyrazem zadaniowego podejścia do radzenia sobie z problemami. Koncentracja na zdrowym odżywianiu, związana z Aktywnym Radzeniem Sobie, wydaje się szczególnie istotna w sytuacji stresu związanego z chorobami dietozależnymi. Istotna statystycznie jest również zależność między Poszukiwaniem Wsparcia a typem postawy żywieniowej opartym na religijności. Analiza korelacyjna Tau-b Kendalla w grupach wyodrębnionych ze względu na płeć jednak nie potwierdza tej zależności.

Czynnik Zachowania Unikowe, obejmujący takie strategie, jak: Zajmowanie się Czymś Innym, Zaprzeczanie i Wyładowanie, koreluje w sposób istotny statystycznie z typem postawy żywieniowej określanej jako anorektyczny dietetyzm. Gotowość do odchudzania może być wyjaśniana w kategoriach unikania problemów. Można przypuszczać, że w przypadku osób niemających problemu z nadmierną masą ciała podejmowanie diet odchudzających stanowi ucieczkę od problemów życia codziennego. Zachowania unikowe korelują również dodatnio z postawą hedonistyczną, manifestującą się głównie nadmiernym jedzeniem, lecz zależność ta jest istotna statystycznie tylko w grupie badanych kobiet. Jednocześnie w grupie studentów mężczyzn warto zauważyć istotne statystycznie korelacje dodatnie między zachowaniami unikowymi a postawą religijną i ortorektyczno-eksperymentalną wobec własnego sposobu odżywiania. Zależności te sugerują, że w przypadku badanych mężczyzn formą ucieczki od stresu jest eksperymentowanie ze zdrowymi dietami oraz umiar w jedzeniu wynikający z postawy wobec odżywiania opartej na religijności. Związek między postawami żywieniowymi a zachowaniami unikowymi jako strategiami radzenia sobie ze stresem jest modyfikowany przez płeć, przy czym sposób odżywiania kobiet stanowi tutaj większe zagrożenie dla zdrowia niż w przypadku traktowania jedzenia w kategoriach unikowego radzenia sobie mężczyzn. 
W strukturze czynnikowej Mini-COPE odrębny czynnik stanowi strategia radzenia sobie określana jako Zwrot ku Religii. W sposób istotny statystycznie koreluje ona z religijną postawą żywieniową. Taka zależność może świadczyć o tym, że postawa żywieniowa oparta na religijności, uwzględniająca przestrzeganie okresowego postu i umiar w jedzeniu, może być wyjaśniana w kategoriach radzenia sobie ze stresem. Osobom wierzącym przestrzeganie praktyk religijnych związanych z jedzeniem pomaga w przezwyciężaniu problemów życia codziennego.

Postawy żywieniowe nie są przypisane do jednostek w sposób wyłączny, ale współwystępują z różnym nasileniem. W celu wyodrębnienia najczęściej powiązanych ze sobą postaw wobec odżywiania przeprowadzono u badanych studentów kierunków nauczycielskich analizę skupień metodą EM opartą na prawdopodobieństwie. Algorytm ten ma na celu ustalenie parametrów rozkładów segmentów na podstawie rozkładu całej grupy oraz przydzielenie obserwacji do najbardziej odpowiadających im segmentów (Migut 2009, s. 78-79). Zastosowano model statystyczny ze środowiska $\mathrm{R}$ z wyodrębnieniem czterech skupień (komponentów) Mclust VVI (diagonal, varying, volume and shape).

Zależności między typami postaw żywieniowych a profilami badano za pomocą jednoczynnikowej analizy wariancji, której wyniki przedstawia tab. 4.

Tab. 4. Nasilenie postaw żywieniowych w profilach postaw żywieniowych badanych studentów analiza różnic średnich

\begin{tabular}{|c|c|c|r|r|r|r|r|c|}
\hline Zmienna zależna & & $\begin{array}{c}\text { Ogółem } \\
\mathrm{N}=387\end{array}$ & $\begin{array}{c}\text { Profil 1 } \\
\mathrm{n}=194\end{array}$ & $\begin{array}{c}\text { Profil 2 } \\
\mathrm{n}=37\end{array}$ & $\begin{array}{c}\text { Profil 3 } \\
\mathrm{n}=100\end{array}$ & $\begin{array}{c}\text { Profil 4 } \\
\mathrm{n}=56\end{array}$ & $\begin{array}{c}\text { One-way } \\
\text { ANOVA }\end{array}$ & Istotność \\
\hline \multirow{2}{*}{$\begin{array}{c}\text { Anorektyczny } \\
\text { dietetyzm }\end{array}$} & $\mathrm{M}$ & 41,21 & 46,85 & 56,51 & 26,31 & 38,16 & 210,98 & $<0,001$ \\
\cline { 2 - 10 } & $\mathrm{SD}$ & 14,01 & 9,51 & 11,48 & 5,90 & 15,14 & & \\
\hline \multirow{2}{*}{ Religijny } & $\mathrm{M}$ & 28,94 & 33,14 & 30,49 & 29,62 & 12,11 & 370,36 & $<0,001$ \\
\cline { 2 - 10 } & $\mathrm{SD}$ & 11,76 & 10,52 & 11,32 & 8,92 & 1,44 & & \\
\hline \multirow{2}{*}{ Wegetariański } & $\mathrm{M}$ & 14,90 & 14,55 & 26,16 & 12,97 & 12,14 & 60,87 & $<0,001$ \\
\cline { 2 - 10 } & $\mathrm{SD}$ & 5,13 & 3,35 & 6,27 & 2,52 & 2,77 & & \\
\hline \multirow{2}{*}{ Hedonistyczny } & $\mathrm{M}$ & 32,55 & 32,67 & 34,46 & 30,43 & 34,66 & 4,81 & 0,003 \\
\cline { 2 - 10 } & $\mathrm{SD}$ & 7,32 & 6,59 & 8,55 & 6,77 & 8,81 & & \\
\hline \multirow{2}{*}{$\begin{array}{c}\text { Ortorektyczno- } \\
\text {-eksperymentalny }\end{array}$} & $\mathrm{M}$ & 32,07 & 34,94 & 33,89 & 27,26 & 29,50 & 52,88 & $<0,001$ \\
\cline { 2 - 9 } & $\mathrm{SD}$ & 6,21 & 4,80 & 6,18 & 5,45 & 5,63 & & \\
\hline
\end{tabular}

Źródło: badanie własne.

Zróżnicowanie średnich wartości wszystkich typów postaw żywieniowych względem czterech profili postaw żywieniowych wyłonionych w wyniku analizy skupień jest istotne statystycznie. Analiza danych zawartych w tab. 4 pozwala na opis profili za pomocą budujących je postaw żywieniowych. 
Profil 1 - reprezentowany przez 50\% badanych - charakteryzuje się podwyższonymi wartościami następujących postaw: anorektyczny dietetyzm, religijnej, ortorektyczno-eksperymentalnej. Najwyższe różnice względem średniej postawy dla całej badanej grupy zaobserwowano w zakresie postawy religijnej oraz związanej z eksperymentami dietetycznymi. Brak jest istotnych różnic w zakresie postawy wegeteriańskiej oraz hedonistycznej między reprezentantami tego profilu a ogółem badanych. Analiza typów postaw żywieniowych przedstawicieli tego profilu pozwala określić go jako tradycyjnie religijny, zrównoważony. Połowa badanych wydaje się prezentować stosunek wobec odżywiania raczej korzystny dla zdrowia, zakorzeniony w tradycji religijnej.

Profil 2 - najmniej liczny, niespełna 10\% badanych - cechuje najwyższy poziom postawy anorektyczny dietetyzm i wegetariańskiej oraz nieznacznie podwyższone nasilenie postawy religijnej, hedonistycznej i ortorektyczno-eksperymentalnej. Osoby reprezentujące ten profil wykazują zainteresowanie odchudzaniem, eksperymentami dietetycznymi, a zwłaszcza dietą wegetariańską.

Profil 3 - zbudowany przez $26 \%$ badanych - charakteryzuje się najniższym poziomem anorektycznego dietetyzmu i postawy ortorektyczno-eksperymentalnej oraz nieznacznie obniżonymi wartościami postawy wegetariańskej i hedonistycznej. Postawa religijna pozostaje na średnim poziomie, jednak - w porównaniu do niskiego nasilenia pozostałych postaw - wyraźnie dominuje w tym profilu. Problematyka diet, odchudzania i kulinariów wydaje się obojętna dla osób reprezentujących ten profil żywieniowy.

Profil 4 - obejmujący 14\% respondentów - cechuje bardzo niski poziom postawy religijnej, obniżone nasilenie anorektycznego dietetyzmu, postawy wegetariańskiej oraz ortorektyczno-eksperymentalnej. Typ postawy hedonistyczny wykazuje najwyższą wartość średnią w porównaniu do pozostałych profili. Stosunkowo wysoki poziom postawy hedonistycznej przy jednoczesnym obniżeniu poziomu wszystkich pozostałych postaw (szczególnie religijnych) świadczy o konsumpcyjnym stosunku do odżywiania, bez ograniczeń dietetycznych, lekceważącym religijną etykę umiaru.

W celu zbadania zależności między profilami postaw żywieniowych a strategiami radzenia sobie ze stresem porównano różnice między średnimi wartościami w siedmiu czynnikach Mini-COPE. Istotność różnic zbadano za pomocą jednoczynnikowej analizy wariancji (por. tab. 5).

$\mathrm{Z}$ analizy danych zawartych w tab. 5 wynika, że strategie aktywnego radzenia sobie ze stresem najczęściej są stosowane przez osoby o tradycyjnym, zrównoważonym profilu postaw żywieniowych, u których występuje największe nasilenie postawy ortorektyczno-eksperymentalnej. Oznacza to, że istnieje związek między aktywnym radzeniem sobie w sytuacjach trudnych a korzystnym (z punktu widzenia zdrowia) sposobem odżywiania. Można również przypuszczać, że w przypadku stresu spowodowanego problemami zdrowotnymi aktywne radzenie 
Tab. 5. Strategie radzenia sobie ze stresem w profilach postaw żywieniowych - analiza różnic średnich

\begin{tabular}{|c|c|c|c|c|c|c|c|}
\hline $\begin{array}{c}\text { Strategie } \\
\text { radzenia sobie }\end{array}$ & $\begin{array}{l}\text { Ogółem } \\
\text { M (SD) }\end{array}$ & $\begin{array}{l}\text { Profil } 1 \\
\text { M (SD) }\end{array}$ & $\begin{array}{l}\text { Profil } 2 \\
\text { M (SD) }\end{array}$ & $\begin{array}{l}\text { Profil } 3 \\
\text { M (SD) }\end{array}$ & $\begin{array}{l}\text { Profil } 4 \\
\text { M (SD) }\end{array}$ & $\begin{array}{l}\text { One-way } \\
\text { ANOVA }\end{array}$ & Istotność \\
\hline $\begin{array}{c}\text { Aktywne } \\
\text { Radzenie } \\
\text { Sobie }\end{array}$ & $4,12(1,04)$ & $4,28(0,95)$ & $3,87(1,14)$ & $3,93(1,05)$ & $4,05(1,18)$ & 3,55 & 0,017 \\
\hline Bezradność & $1,90(1,10)$ & $1,93(1,04)$ & $2,43(1,22)$ & $1,65(0,94)$ & $1,89(1,34)$ & 4,69 & 0,004 \\
\hline $\begin{array}{c}\text { Poszukiwanie } \\
\text { Wsparcia }\end{array}$ & $4,21(1,38)$ & $4,35(1,34)$ & $3,85(1,51)$ & $4,12(1,33)$ & $4,13(1,47)$ & 1,58 & 0,198 \\
\hline $\begin{array}{c}\text { Zachowania } \\
\text { Unikowe }\end{array}$ & $2,96(1,08)$ & $3,09(1,02)$ & $3,34(1,11)$ & $2,73(0,98)$ & $2,70(1,26)$ & 5,11 & 0,002 \\
\hline $\begin{array}{l}\text { Zwrot ku } \\
\text { Religii }\end{array}$ & $2,39(1,94)$ & $2,71(1,87)$ & $2,78(1,97)$ & $2,62(1,87)$ & $0,57(1,22)$ & 39,90 & $<0,001$ \\
\hline Akceptacja & $3,80(1,28)$ & $3,93(1,24)$ & $3,68(1,29)$ & $3,56(1,23)$ & $3,86(1,47)$ & 2,09 & 0,106 \\
\hline $\begin{array}{l}\text { Poczucie } \\
\text { Humoru }\end{array}$ & $2,19(1,39)$ & $2,24(1,41)$ & $2,51(1,41)$ & $1,97(1,21)$ & $2,18(1,61)$ & 1,77 & 0,156 \\
\hline
\end{tabular}

Źródło: badanie własne.

sobie wyraża się zainteresowaniem zdrowym sposobem odżywiania. Mając na uwadze fakt, że wiele chorób uwarunkowanych jest niewłaściwymi postawami i nawykami żywieniowymi, a dietoterapia może w istotny sposób wspomagać proces leczenia, należy pozytywnie ocenić aktywne radzenie sobie z problemami zdrowotnymi poprzez zmianę sposobu odżywiania na bardziej prozdrowotny.

Jednocześnie warto zauważyć, że wśród osób reprezentujących profil dietetyczny, które mają skłonność do eksperymentowania z dietami odchudzającymi, występuje najwyższe nasilenie bezradności, zachowań unikowych oraz zwrotu ku religii jako strategii radzenia sobie ze stresem. Można sądzić, że gotowość odchudzania się czy eksperymentowania z dietami (np. wegetariańskimi) jest wyrazem nie tylko troski o zdrowie czy chęci redukcji nadmiernej masy ciała, ale także bierności w radzeniu sobie z problemami życia codziennego.

\section{DYSKUSJA}

Postawa żywieniowa, rozumiana jako stosunek do własnego sposobu odżywiania, może stanowić sposób radzenia sobie ze stresem w ujęciu dyspozycyjnym, czyli względnie stałą, specyficzną dla jednostki, tendencję do zachowania się w określony sposób w sytuacji stresowej (Juczyński, Ogińska-Bulik 2012, s. 24). Analiza psychospołecznych funkcji jedzenia pozwala zauważyć, że sięganie po przekąski bądź „pochłanianie” pożywienia pozwala (przynajmniej na chwilę) uwolnić się od złego nastroju, uspokoić emocje, zredukować napięcie i stres (Niewiadomska, Kulik, Hajduk 2005, s. 18-22). Wyniki badań zależno- 
ści między stresem a jedzeniem wskazują, że związek ten jest złożony, a reakcją na stres może być nie tylko objadanie się, ale również ograniczanie jedzenia. W badaniach prowadzonych wśród amerykańskich studentów wykazano, że stres sprzyja sięganiu po przekąski, jednocześnie powodując ograniczenie spożywania zwykłych posiłków (Ogden 2011, s. 61-64). Natomiast inne badania studentów ujawniły brak znaczących zmian w sposobie odżywiania w sytuacji stresu spowodowanego sytuacją egzaminacyjną. Te niejednoznaczne wyniki badań nad sposobem odżywiania jako strategią radzenia sobie są wyjaśniane jako „paradoks stresu i jedzenia", który różnicują zmienne pośredniczące o charakterze socjodemograficznym (Eßwein, Carlsohn, Kohlmann 2017, s. 133).

$\mathrm{W}$ badaniach własnych ograniczenie jedzenia było związane z postawą anorektyczny dietetyzm, zaś nadmierne jedzenie - z postawą hedonistyczną. Obydwie postawy korelują w sposób istotny statystycznie z biernymi strategiami radzenia sobie (jak bezradność, akceptacja, zachowania unikowe). Bierność w radzeniu sobie ze stresem i codziennymi problemami może się manifestować zarówno unikaniem jedzenia, nieuzasadnionym odchudzaniem, jak i nawykowym bądź emocjonalnym objadaniem się prowadzącym do nadwagi i otyłości.

Warto podkreślić, że zależności między biernymi strategiami radzenia sobie a postawą anorektyczną i hedonistyczną są różnicowane przez płeć jako zmienną pośredniczącą, przy czym częściej korelacje istotne statystycznie są obserwowane u kobiet. Spostrzeżenie to częściowo znajduje potwierdzenie w literaturze przedmiotu. Dyskusję wyników badań własnych z doniesieniami innych badaczy utrudnia fakt, że zależności te są eksplorowane głównie wśród kobiet (Ogińska-Bulik 2004; Todd, Baumeister 1991; Tran, Ferguson, Myers).

W grupie badanych mężczyzn istnieje istotna statystycznie zależność między zachowaniami unikowymi a postawą ortorektyczną i religijną. W analizie profili postaw żywieniowych postawy dominują w profilu 1 (najbardziej korzystnym z punktu widzenia zdrowia), który jest niezależny od płci badanych studentów. Wśród osób reprezentujących ten profil najczęściej obserwuje się aktywne strategie radzenia sobie ze stresem. Można zatem przypuszczać, że prozdrowotny sposób odżywiania powiązany z praktykowaniem religijności w przypadku badanych mężczyzn stanowi strategię unikania stresu, zaś dla badanych kobiet jest przejawem aktywnego radzenia sobie z problemami. Zdrowa dieta należy do najskuteczniejszych strategii radzenia sobie ze stresem, zwłaszcza jeśli jest on spowodowany chorobami somatycznymi (Bilsker, Samra, Goldner 2009). Badania nad sposobami odżywiania warunkowanymi religijnością pozwalają zauważyć, że postawa religijna stanowi czynnik obniżający występowanie zaburzeń żywieniowych, sprzyja zatem prozdrowotnym postawom wobec odżywiania oraz szeroko rozumianemu zdrowiu. Zależności te są jednak obserwowane głównie u kobiet (Akrawi i in. 2015, s. 29). 
Bierne strategie radzenia sobie ze stresem (bezradność, akceptacja, zachowania unikowe) są najczęściej obserwowane w profilu 2, reprezentowanym głównie przez studentki skoncentrowane na dietach odchudzających, związanych z anorektyczną postawą żywieniową. Wyniki te dopełniają analizowaną wyżej tezę o zależności między prozdrowotnym sposobem odżywiania a aktywnym radzeniem sobie ze stresem.

\section{WNIOSKI}

Zależności między postawami żywieniowymi a radzeniem sobie ze stresem są niejednoznaczne i złożone. Zarówno zrównoważone, korzystne dla zdrowia postawy wobec odżywiania, jak i antyzdrowotne, związane z nadmiernym jedzeniem oraz odchudzaniem, mogą być postrzegane jako strategie radzenia sobie ze stresem i codziennymi problemami.

Postawy prozdrowotne stanowią zwykle aktywne strategie radzenia sobie, podczas gdy niekorzystne dla zdrowia postawy żywieniowe są związane z biernością w radzeniu sobie ze stresem.

Zależności między sposobem odżywiania oraz radzeniem sobie ze stresem statystycznie częściej są obserwowane u kobiet, co może sugerować, że ich postawy żywieniowe - oceniane jako prozdrowotne bądź antyzdrowotne - w większym stopniu niż w przypadku mężczyzn mogą być postrzegane jako strategie radzenia sobie.

Badani studenci kierunków nauczycielskich to młodzi dorośli, których sposób odżywiania wynika w znacznym stopniu z własnych przekonań, decyzji i doświadczeń emocjonalno-poznawczych. Ich postawy żywieniowe, jako konstrukty względnie trwałe, mają istotne znaczenie dla zdrowia. Postrzeganie jedzenia jako strategii radzenia sobie ze stresem i codziennymi problemami może stanowić zagrożenie zdrowotne.

Prawdopodobnie część badanych to przyszli nauczyciele, którzy poprzez modelowanie będą kształtować u dzieci i młodzieży postawy wobec odżywiania oraz uczyć, jak radzić sobie ze stresem. Prozdrowotne postawy żywieniowe oraz efektywne strategie radzenia sobie studentów kierunków nauczycielskich mogą okazać się znaczące z punktu widzenia szkolnej edukacji zdrowotnej.

\section{BIBLIOGRAFIA}

Abucewicz M. (2008), Ideologiczne wymiary kontroli społecznej - perspektywa krytyczna, [w:] J. Kwaśniewski (red.), Profilaktyka społeczna i resocjalizacja, Warszawa: Instytut Profilaktyki Społecznej i Resocjalizacji UW.

Akrawi D., Batrop R., Potter U., Touz S. (2015), Religiosity, spirituality in relations to disordered eating and body image concerns: A systematic review, "Journal of Eating Disorders", Vol. 3(29), DOI: https://doi.org/10.1186/s40337-015-0064-0. 
Babicz-Zielińska E., Zabrocki R. (2007), Postawy konsumentów wobec prozdrowotnej wartości żywności, „Żywność. Nauka. Technologia. Jakość”, nr 6(55).

Bilsker D., Samra J., Goldner E. (2009), Positive Coping with Health Conditions. A Self-Care Workbook, www.sfu.ca/carmha/publications/positive-coping-with-health-conditions.html (dostęp: 27.06.2017).

Borowiec A., Lignowska I. (2012), Czy ideologia healthismu jest cecha dystynktywna klasy średniej w Polsce?, „Kultura i Społeczeństwo”, nr 2.

Buczak A. (2017), Szacunek jako element postawy wobec odżywiania - w poszukiwaniu sprawności moralnych w edukacji żywieniowej, [w:] I. Jazukiewicz, E. Rojewska (red.), Sprawności moralne a przestrzenie pedagogiczne, Szczecin: Wydawnictwo Naukowe Uniwersytetu Szczecińskiego.

Dyczewska A. (2006), Światopogląd na talerzu. Wegetarianizm jako przejaw wspótczesnej religijności, Kraków: Zakład Wydawniczy „Nomos”.

Eßwein R., Carlsohn A., Kohlmann C.W. (2017), Einfluss von Prüfungen auf emotionales Befinden und Ernährung? Eine Pilotstudie mit Bachelorstudierenden der Gesundheitsförderung, ,Prävention und Gesundheitsförderung“, Bd. 12(2),

\section{DOI: https://doi.org/10.1007/s11553-016-0569-7.}

Fiske J. (1999), Wprowadzenie do badań nad komunikowaniem, Wrocław: Astrum.

Głębocka A. (2010), Niezadowolenie z wyglądu a rozpaczliwa kontrola wagi, Kraków: Oficyna Wydawnicza „Impuls”.

Józefik B. (2010), Kultura, ciało, (nie)jedzenie. Terapia. Perspektywa narracyjno-konstrukcjonistyczna w zaburzeniach odżywiania, Kraków: Wydawnictwo Uniwersytetu Jagiellońskiego.

Juczyński Z., Ogińska-Bulik N. (2012), Narzędzia Pomiaru Stresu i Radzenia Sobie ze Stresem. Podręcznik, Warszawa: Pracownia Testów Psychologicznych PTP.

Kędra E. (2011), Zaburzenia odżywiania - znak naszych czasów, „Pielęgniarstwo i Zdrowie Publiczne", $\mathrm{nr} 1(2)$.

Kowalewska J., Graeber P. (2003), Ksztaltowanie postaw zdrowotnych, „Życie Szkoły”, nr 1.

Kwasek M., Obiedzińska A. (2014), Z badań nad rolnictwem społecznie zrównoważonym. (26) Zrównoważone systemy rolnicze i zrównoważona dieta, Warszawa: Instytut Ekonomiki, Rolnictwa i Gospodarki Żywnościowej - Państwowy Instytut Badawczy.

Leszczyński B. (2014), Znaczenie i symbolika postu, „Studia Koszalińsko-Kołobrzeskie”, nr 21.

Makara-Studzińska M., Buczyjan A., Morylowska J. (2007), Jedzenie-przyjaciel $i$ wróg. Konteksty psychologiczne otyłości. Przegląd piśmiennictwa, „Zdrowie Publiczne”, nr 117(3).

Mariański J. (2004), Religijność społeczeństwa polskiego. Próba syntezy socjologicznej, Kraków: Zakład Wydawniczy „Nomos”.

Migut G. (2009), Zastosowanie technik analizy skupień i drzew decyzyjnych do analizy rynku, https://media.statsoft.pl/_old_dnn/downloads/zastosowanie_technik.pdf (dostęp: 10.09.2018).

Narojek L. (1993), Niektóre aspekty uwarunkowań zachowań żywieniowych, Warszawa: Wydawnictwo SGGW.

Niewiadomska I., Kulik A., Hajduk A. (2005), Jedzenie, Lublin: Wydawnictwo KUL.

Ogden J. (2011), Psychologia odżywiania się. Od zdrowych do zaburzonych zachowań żywieniowych, Kraków: Wydawnictwo Uniwersytetu Jagiellońskiego. 
Ogińska-Bulik N. (2004), Psychologia nadmiernego jedzenia. Przyczyny - konsekwencje - sposoby zmiany, Łódź: Wydawnictwo Uniwersytetu Łódzkiego.

Ogińska-Bulik N. (2016), Wiem, co jem. Psychologia nadmiernego jedzenia i odchudzania się, Kraków: Wydawnictwo Uniwersytetu Jagiellońskiego.

Singer P., Mason J. (2012), Etyka a to, co jemy, Warszawa: Wydawnictwo Czarna Owca.

Sołtysiak T. (2013), Młode kobiety w , szponach opętania” szczuplych i zgrabnych sylwetek, „Lubelski Rocznik Pedagogiczny”, nr 32.

Todd E.H., Baumeister R.E. (1991), Binge eating as escape from self-awareness, "Psychological Bulletin", Vol. 110(1).

Tran T.H., Ferguson J., Myers Ch.A., The effects of avoidance coping, neuroticism, gender role identity, and preceived stress on emotional eating, https://www2.ccga.edu/ServiceLearning/ files/Symposium (dostęp: 27.06.2017).

Wojciszke B. (2013), Psychologia społeczna, Warszawa: Wydawnictwo Naukowe „Scholar”.

Woynarowska B. (2017a), Terminologia, cele i koncepcje wspótczesnej edukacji zdrowotnej, [w:] B. Woynarowska (red.), Edukacja zdrowotna. Podstawy teoretyczne - metodyka - praktyka, Warszawa: Wydawnictwo PWN.

Woynarowska B. (2017b), Dbałość ludzi o zdrowie, [w:] B. Woynarowska (red.), Edukacja zdrowotna. Podstawy teoretyczne - metodyka - praktyka, Warszawa: Wydawnictwo PWN.

Woźniak B. (2013), Regulacyjna funkcja religii a sposób odżywiania się i zdrowie osób zaangażowanych religijnie, [w:] B. Tobiasz-Adamczyk (red.), Od socjologii medycyny do socjologii żywienia, cz. 2: Wybrane aspekty socjologii żywienia, Kraków: Wydawnictwo Uniwersytetu Jagiellońskiego.

Ziemlański Ś., Budzyńska-Topolowska J. (1997), Wegetarianizm w świetle nauki o żywności i żywieniu, Warszawa: Instytut Danone - Fundacja Promocji Zdrowego Żywienia.

Ziółkowska B. (2001), Ekspresja syndromu gotowości anorektycznej u dziewcząt w stadium adolescencji, Poznań: Wydawnictwo Fundacji Humaniora.

Zwoliński A. (2006), Jedzenie w relacjach spolecznych, Kraków: Wydawnictwo Naukowe Papieskiej Akademii Teologicznej.

Zwoliński A. (2008), Wychowanie do umiaru, „Pedagogika Katolicka”, nr 2(1).

\section{SUMMARY}

Dietary attitudes understood as a relation to one's own diet, including the cognitive, emotional and behavioral components, have a source in the worldview of the individual. In the course of work on the author's Scale of Nutritional Stance, five types of attitudes towards nutrition were identified. Although these attitudes are not evaluated in terms of pro-health - anti-health, the high severity of each of them may have negative health consequences. One of the correlates of nutritional attitudes may be coping strategies, and the diet (e.g. slimming down, experimenting with diets, religious fasting, or excessive eating) can be seen in terms of coping with the problems of everyday life.

The group of respondents consists of 387 students of teaching faculties, young adults who make the first conscious dietary decisions. Probably some of them will work with children and youth 
in the future and influence the way students are fed. In own research, in addition to the author's tool for studying nutritional attitudes, the Mini-COPE scale was used to analyze coping strategies. The analysis of the research results showed that the relationships between eating habits and coping are more often observed in women. Both excessive eating and slimming are treated by the researched students in terms of avoiding stress.

Keywords: eating attitudes; coping; health; students 